\title{
Spondylolisthesis mimicking the progression of dissection in a case of chronic Stanford type B aortic dissection
}

\author{
Kronik Tip-B aort diseksiyonlu bir olguda diseksiyonun ilerlemesini taklit eden \\ lomber spondilolistezis
}

\author{
Mustafa GÖZ, ${ }^{1}$ Mehmet Fuat TORUN, ${ }^{2}$ Cengiz MORDENIZ, ${ }^{3}$ Mehmet Salih AYDIN, ${ }^{1}$ \\ Abbas Heval DEMIIRKOL, ${ }^{1}$ Hamza KARABAG $\breve{G}^{2}$
}

\begin{abstract}
Aortic dissection is an acute lethal cardiovascular condition. A 67-year-old hypertensive woman was admitted to our Emergency Department with an abrupt onset of tearing pain in the interscapular area. A thoracic computed tomography scan with contrast showed chronic type B aortic dissection. The patient was transferred to intensive care and medical therapy was initiated. Upon spread of the pain to the lumbar area, the dissection was thought to have progressed. The patient, being hemodynamically stable, was examined using ultrasonography, and the dissection did not show any progression. In the neurological examination for the lumbar pain, the lumbar processus spinosus was found to be sensitive, and the sciatic nerve stretch test was positive at 30 degrees. Magnetic resonance imaging revealed spondylolisthesis and a centrally located disc herniation at the L3-4 level. No operation for the dissection was planned, but discectomy and fusion surgery was scheduled. Since the patient refused surgery, she was discharged with medical therapy. Our aim in this report was to emphasize the importance of spondylolisthesis mimicking the progression of dissection in the differential diagnosis of a chronic type B aortic dissection case.
\end{abstract}

Key Words: Aortic dissection; spondylolisthesis.
Aort diseksiyonu akut ve ölümcül olan kardiyovasküler bir durumdur. Altmış yedi yaşında hipertansif kadın hasta, ani başlayan, bıçak saplanır tarzında alt sırt ağrısı nedeniyle, acil servise geldi. Kontrastl toraks tomografisinde kronik Tip-B aort diseksiyonu tanısı konuldu. Yoğun bak1ma transfer edilen hastaya medikal tedavi başlandi. Hastanın ağrılarının lomber bölgeye yayılması nedeniyle diseksiyonun ilerlediği düşünüldü. Hemodinamik olarak stabil hastaya karın ultrasonografisi yapıldı ve diseksiyonun ilerlemediği görüldü. Nörolojik incelemesinde lomber spinoz proçes hassasiyeti, her iki bacak germe testinin 30 derecede pozitif olması üzerine cekilen manyetik rezonans görüntülemede L3-L4'te spondilolistezis ve merkez yerleşimli disk hernisi tespit edildi. Mevcut bulgularla diseksiyon yönünden operasyon endikasyonu olmadığı düşünüldü. Diskektomi ve füzyon cerrahisi önerildi. Hastanın cerrahi tedaviyi kabul etmemesi üzerine, ilaç tedavisi verilerek taburcu edildi. Bu çalışmada, kronik Tip-B aort diseksiyonlu bir olguda diseksiyonun ilerlemesini taklit eden lomber spondilolistezis'in ayırıcı tanıdaki önemini vurgulamay1 amaçladık.

Anahtar Sözcükler: Aort diseksiyonu; spondilolistezis.
Aortic dissection is an aortic wall condition. All the mechanisms weakening the media layer cause aortic dissection by increasing the stress applied to the wall. Early diagnosis and prompt therapy together are lifesaving in this patient group. ${ }^{[1]}$ In the differential diagnosis, cardiac, pulmonary and musculoskeletal system and hepatobiliary diseases etc. are to be kept in mind. Degenerative spondylolisthesis (DS) is common in elderly patients. ${ }^{[2]}$
It is characterized by the displacement, usually anteriorly, of one vertebral body upon another. Lumbar DS is a major cause of spinal canal stenosis and is often related to low back and leg pain. ${ }^{[2-4]}$

The aim of this paper was to emphasize the importance of spondylolisthesis mimicking the progression of dissection in the differential diagnosis of a chronic type B aortic dissection case. Faculty of Medicine, Şanlıurfa, Turkey. Şanliurfa. 


\section{CASE REPORT}

A 67-year-old woman receiving therapy for hypertension for the previous three years was referred to our department for abrupt onset of tearing pain in the interscapular area. In her echocardiograph, a suspected flap was seen, and in the following thorax computerized tomography (CT), chronic type B aortic dissection was diagnosed. Thorax $\mathrm{CT}$ showed a dilatation in the descending aorta up to $4 \mathrm{~cm}$ in diameter and its chronic dissection (Fig. 1). Although the patient had chronic obstructive pulmonary disease with older age, no organ hypoperfusion or uncontrollable hypertension was detected. The patient was transferred to intensive care and medical therapy was started. Spreading of the pain to the lumbar area and high risk factors led us to consider progression of the dissection. The patient was hemodynamically stable and her abdomen was examined through ultrasonography, but no sign of progression was found. In the neurological examination, the lumbar processus spinosus was found to be sensitive, and the sciatic nerve stretch test was found positive at 30 degrees. In her conventional lumbosacral radiography, spondylolisthesis was diagnosed at the L3-4 level. In her magnetic resonance imaging (MRI), along with spondylolisthesis, a centrally located disc herniation was determined (Fig. 2). No operation for the dissection was indicated by the findings. Discectomy and fusion surgery were indicated by the patient's score of 60 on the Karnofsky scale, her complaint of neurogenic claudication at 25 meters, and the positive results in both legs at 30 degrees in the leg stretch test. Refusing surgical treatment, the patient was discharged with medical therapy.

\section{DISCUSSION}

Early diagnosis and prompt therapy are very important in aortic dissection. The most commonly seen clinical finding is abrupt onset of severe chest and back pain. Especially in type B dissection cases, the

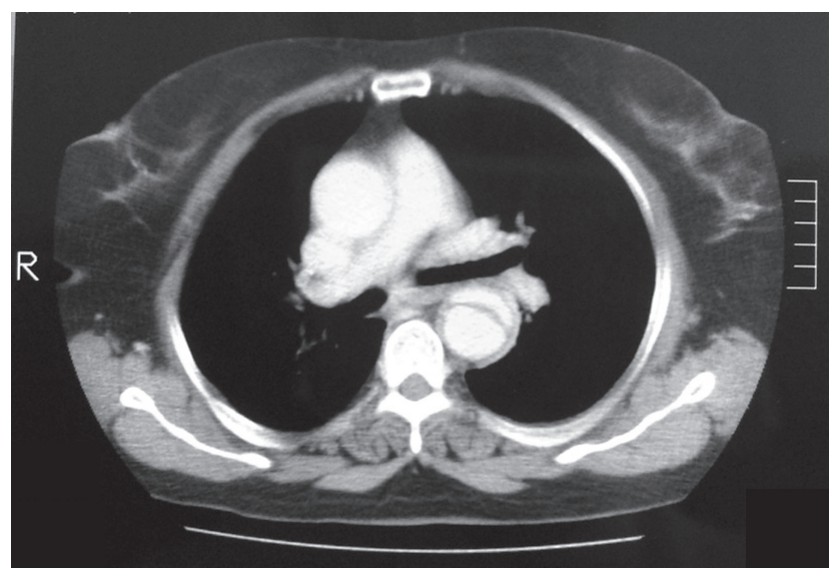

Fig. 1. Type B chronic dissection in computerized tomography with contrast. Descending aortic diameter was found to be $4 \mathrm{~cm}$. differential diagnosis should be made with a detailed radiological imaging method following a very thorough physical examination. Differential diagnoses should include musculoskeletal pathologies.

Degenerative spondylolisthesis (DS) with foraminal stenosis is common in elderly patients. When symptomatic, severe pain and the resultant neurogenic claudication often lead to a diminished quality of life. ${ }^{[2]}$ The Karnofsky performance status scale was designed to measure the patient's activity level and medical care requirements. ${ }^{[5]} \mathrm{A}$ score of 50-70 indicates inability to work, but ability to live at home with varying amounts of assistance required for most personal needs. The score was 60 in this case. Although the diagnosis is easily made on radiographic evaluation, the pathoetiology and appropriate treatment modality are not always as clear. ${ }^{[4]}$

A nonsurgical approach is an appropriate first step. Nonoperative treatment should be the initial course of action in most cases of DS, with or without neurologic symptoms. ${ }^{[2]}$ Treatment options include the use of analgesics and non-steroidal anti-inflammatory drugs (NSAIDs) to control pain. However, those who suffer from neurological symptoms, such as intermittent claudication or vesicorectal disorder, will most probably experience neurological deterioration if they are not operated. ${ }^{[3]}$ Treatment of this pathology has evolved over the past 20 years with the publication of numerous prospective randomized trials assessing the influence of fusion and instrumentation following decompression. Recently, soft-tissue stabilization devic-

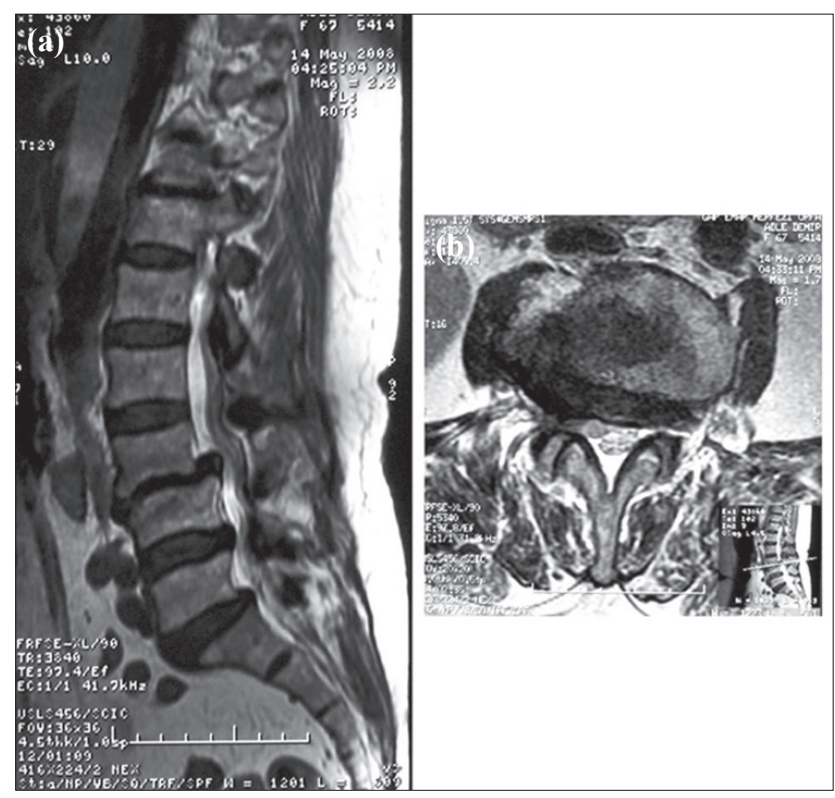

Fig. 2. (a) Sagittal MRI at T2 demonstrates spondylolisthesis at L3-4 level and narrowing of this subarachnoidal space due to the disc herniation; (b) bilateral narrowing of the neural foramen at the axial plane at T2; and especially edema at the neural root of the right L3. 
es have been advocated as an alternative to fusion. ${ }^{[2]}$

In our case, the nerve root at L3 was displaced anteriorly due to spondylolisthesis and central disc herniation, which caused back pain and pain in both legs, limiting the patient's daily activities. Additionally, the patient described neurogenic claudication, and the bilateral leg stretch test was found positive at 30 degrees. Spreading of the pain to the lumbar area can be associated with the dissection. However, in this reported case, the cause of the pain was related to spondylolisthesis. Therefore, discectomy and instrumented fusion by posterior approach were planned. The patient refused surgical treatment and was discharged. She was advised to try a lumbar corset, an anti-inflammatory treatment and a physical exercise program.

In conclusion, the differential diagnosis of aortic dissection is quite difficult in many cases. Thus, we think that spinal pathologies should be considered in the differential diagnosis of dissection.

\section{REFERENCES}

1. Shirakabe A, Hata N, Yokoyama S, Shinada T, Suzuki Y, Kobayashi N, et al. Diagnostic score to differentiate acute aortic dissection in the emergency room. Circ J 2008;72:986-90.

2. Majid K, Fischgrund JS. Degenerative lumbar spondylolisthesis: trends in management. J Am Acad Orthop Surg 2008;16:208-15.

3. Kalichman L, Hunter DJ. Diagnosis and conservative management of degenerative lumbar spondylolisthesis. Eur Spine J 2008; 17:327-35.

4. Metz LN, Deviren V. Low-grade spondylolisthesis. Neurosurg Clin N Am 2007;18:237-48.

5. Karnofsky D, Abelmann W, Craver L, Burchenal J. The use of nitrogen mustard in the palliative treatment of cancer. Cancer 1948;1:634. 